Review

\title{
The correlation of somatotype of person with the development and course of various diseases: results of Russian research
}

\author{
Vladimir G. Kukes ${ }^{1}$, Vladimir N. Nikolenko ${ }^{1,2}$, Chavdar S. Pavlov ${ }^{1}$, Tatiana S. Zharikova ${ }^{1}$, Valeriy F. Marinin ${ }^{1}$, \\ Leonid A. Gridin ${ }^{1}$
}

${ }^{1}$ I.M. Sechenov First Moscow State Medical University, Moscow, Russia

${ }^{2}$ Lomonosov Moscow State University, Moscow, Russia

Received 19 January 2018, Revised 20 May 2018, Accepted 22 June 2018

(C) 2018, Kukes V.G., Nikolenko V.N., Pavlov C.S., Zharikova T.S., Marinin V.F., Gridin L.A.

(C) 2018, Russian Open Medical Journal

Abstract: Currently there is an increased interest in medical anthropology, the study of constitutional features of the human body and their correlation with the manifestations of various diseases. Modern anthropometric techniques are increasingly used in scientific researches in clinical practice. This review article is devoted to the issues of interrelation between the type of the human constitution and manifestations of various diseases.

Keywords: somatotype, constitution, anthropometry, personalized medicine.

Cite as Kukes VG, Nikolenko VN, Pavlov CS, Zharikova TS, Marinin VF, Gridin LA. The correlation of somatotype of person with the development and course of various diseases: results of Russian research. Russian Open Medical Journal 2018; 7: e0301.

Correspondence to Prof. Vladimir N. Nikolenko. Tel.: +7 964 7751134. E-mail: vn.nikolenko@yandex.ru.

Recently an increasing interest in medical anthropology and anthropometry has been observed among anatomists and clinicians throughout the world [1-6]. In our country, it is largely due to the development of personalized medicine which is one of the priority areas of the "Strategy for the development of medical science in the Russian Federation until 2025" [7]. The introduction of methods of personalized medicine implies the application of the individual approach to the treatment and prevention of diseases necessary for each patient. Personalized medicine will help to increase the effectiveness of therapy, reduce the frequency of side effects and the cost of medical care and improve quality of medical care [8]. Constitutionally and anatomically the population is heterogeneous $[9,10]$. This fact shows that we need to take into account the human somatotype in the diagnosis, prevention, and treatment of various diseases. Thus, the use of the newest methods of personalized medicine (phenotyping of cytochrome P450 isoenzymes, genotyping, evaluation of the activity of various human functional systems) [11] combined with somatotyping in clinical practice will increase the safety and efficacy of pharmacotherapy as well as overall treatment outcomes and the patient's quality of life. The term "constitutional medicine" is used in Japan, China, and South Korea. It means that medicine focused on the clinical application of theoretical knowledge of the human constitution. Simultaneously in Japan, the canons of medicine prescribe to be based only on the human constitution [12].

Particular attention to constitutional anatomy is also caused by revising the limits of the normal range for some anthropometric indicators in different age groups [13] or to obtain for the first time this information e.g. for people of elderly and senile age longlivers $[14,15]$. For example, the somatotype specificity of the body mass index was first proved by the analysis of length and body weight depending on the type of the girls' physique [1].

The need to update and supplement anthropometric data is caused by such processes as temporal variability of parameters, acceleration, gracilization of the constitution, retardation of development, etc. [16-20].

The anthropometric analysis was integrated into clinical practice by using not only the usual algorithms but also high-tech methods such as computer optical topography and bioimpedancemetry which allows estimating the component composition of the human body [21-24]. In addition, the use of anthropometry in clinical practice has already made possible to identify correlations between the somatic constitution and certain diseases [1], somatic parameters and features of the functioning of the immune system $[25,26]$.

It should be noted that there is no single classification of types of constitution. Variety of methods and criteria for determining somatotype has been used in medical research over the years but in Russia it is used the scheme by Bunak in determining the constitutional types of men. According to this scheme, the thoracic, muscular, abdominal and indeterminate somatotypes are distinguished as well as intermediate subtypes (thoraco-muscular, muscular-thoracic, musculo-abdominal and abdominal-muscular; see Table 1) [27, 28]. 
Table 1. Constitutional types of men (Bunak, 1941) [27]

\begin{tabular}{ll}
\hline Type of constitution & \multicolumn{1}{c}{ Description } \\
\hline Thoracic & Small fat deposition, average muscle tone \\
Muscular & Average fat deposition, strong muscle tone \\
Abdominal & Strong fat deposition, average muscle tone \\
\hline
\end{tabular}

Table 2. Constitutional types of women (Galant, 1927) [29]

\begin{tabular}{|c|c|c|}
\hline Category & $\begin{array}{l}\text { Type of } \\
\text { constitution }\end{array}$ & Description \\
\hline \multirow[t]{2}{*}{ Leptosomal } & Asthenic & $\begin{array}{l}\text { Thin body; flat, narrow, elongated chest; } \\
\text { drawn inside the abdomen; narrow } \\
\text { pelvis; long thin limbs; pale, narrow, } \\
\text { elongated face; musculature is poorly } \\
\text { developed; body fat is not expressed }\end{array}$ \\
\hline & Stenoplastic & $\begin{array}{l}\text { Thin body; flat, narrow, elongated chest; } \\
\text { drawn inside the abdomen; narrow } \\
\text { pelvis; long thin limbs; pale, narrow, } \\
\text { elongated face; muscle and adipose } \\
\text { tissue are well developed }\end{array}$ \\
\hline \multirow[t]{2}{*}{ Mesosomal } & Picnic & $\begin{array}{l}\text { Moderate or slightly increased severity } \\
\text { of subcutaneous fat; shortened limbs; } \\
\text { rounded head and face; full shortened } \\
\text { neck; relatively broad round shoulders; } \\
\text { cylindrical chest; wide pelvis with } \\
\text { characteristic fat deposits; rounded hips; } \\
\text { full leg closure }\end{array}$ \\
\hline & Mesoplastic & $\begin{array}{l}\text { Squat figure; significant development of } \\
\text { the tendons of the muscles; moderately } \\
\text { well-developed and hard muscles; } \\
\text { massive skeleton; sufficient } \\
\text { development of subcutaneous fat; broad } \\
\text { face; a strong development of the } \\
\text { cheekbones }\end{array}$ \\
\hline \multirow[t]{3}{*}{ Megalosomal } & Athletic & $\begin{array}{l}\text { Exceptionally strong development of } \\
\text { muscles and skeleton; weak } \\
\text { development of subcutaneous fat; } \\
\text { usually the male type structures of the } \\
\text { pelvis; male facial features }\end{array}$ \\
\hline & Subatletic & $\begin{array}{l}\text { Tall slender women; moderate } \\
\text { development of muscles and } \\
\text { subcutaneous fat }\end{array}$ \\
\hline & Euryplastic & $\begin{array}{l}\text { Strong development of subcutaneous } \\
\text { fat; exceptionally strong development of } \\
\text { muscles and skeleton }\end{array}$ \\
\hline
\end{tabular}

The scheme of women's constitutions by Galant [29] is commonly used in establishing of constitutional diagnosis of women. There are three categories of constitutional types according to this scheme: leptosomal including asthenic and stenoplastic types; mesosomal including picnic and mesoplastic types as well as megalosomal constitutions that combine athletic, subatletic and euryplastic types (Table 2) [30]. Qualitative and quantitative criteria exist for determining each type of body constitution [31] and the frequency of occurrence of different types of constitution in scientific research may differ [27, 30, 32].

Somatotyping is actively used in clinical practice to identify phenotypic predictors of the disease development. So Kapustina et al. found in their study that the majority of women with osteoarthritis had a megalosomal constitution and older patients had smaller values of anthropometric parameters such as height, body weight, and body mass index [33].

Traumatologists and osteopaths also use anthropometric research methods in their practice to individualize the approach to the treatment of diseases in terms of the concept of personalized medicine. Rudenko et al. revealed that the intensity of neurological manifestations and the results of treatment in women with osteochondrosis is affected not only by the size of the hernial protrusion but also by anatomical features of the structure of the spinal column that depends on the somatic constitution. It was noted that the best results of therapy were observed in patients with stenoplastic, indeterminate and subtleties types of physique since it corresponds to intervertebral foramens of a larger size [34].

It should be noted by identifying and preventing of cardiovascular diseases that men with abdominal and abdominalmuscular types of body constitution are predisposed to obesity as they have a strong development of the fat component [35]. Cardiac rhythm and conduction disorders are most often observed in men with muscular somatotype (34\% of cases) and women with euryplastic somatotype $(58 \%)$ [36, 37].

The incidence of primary heart attack in men does not depend on the constitutional type, however transmural acute myocardial infarction in men with abdominal (30\%) and indeterminate (33\%) somatotypes is more common than with thoracic somatotype (14\%). Meanwhile, abdominal somatotype leads to recurrent heart attack more frequent $[38,39]$. The hypertrophy of the left ventricle occurs in men with a muscular type of constitution in $79 \%$ of cases, abdominal - in $66 \%$, thoracic - in $37 \%$ of cases [40].

At the first time, it was shown in the process of studies of phenotypic predictors of asthma that women of the leptosomal type of constitution and men with the chest somatotype predominate among the patients with this disease [41].

The frequency of diseases of the hepatobiliary zone also correlates with the features of the human physique. Thus, chronic cholecystitis and biliary dyskinesia in women develop most often in patients with the megalosomal somatotype [42]. Also people with increased body weight and abdominal obesity are susceptible to these diseases [3].

Study devoted to dependence of gall bladder motility on the type of constitution in women found that hypokinesia with expressed dyspeptic phenomena predominates are in women with leptosomal somatotype, and hyperkinesia is in women with megalosomal (athletic, subatletics) somatotype, while pain syndrome prevails in persons with euryplastic somatotype, and hypo- and hyperkinesia were selected depending on the fat component $[42,43]$.

The study of clinical-anthropometric parallels in patients with liver cirrhosis found that about $50 \%$ of women have a picnic body type and 50\% men have an asthenoid-thoracic type [44].

Polismak described that chronic gastritis, peptic ulcer of the stomach and duodenum are most often (in 27.6\% of cases) observed in patients with an indeterminate type of constitution. Peptic ulcer disease developes in patients with thoracic and muscular somatotypes at a young age, and in patients with abdominal somatotype developes later but with more expressed dyspeptic phenomena. It is interesting to note that patients with asthenic and thoracic somatotypes in this study were almost half as likely as in the population [45].

Derevtsova et al. showed that women with the syndrome of central hemiparesis of the second period of adulthood who have asthenic and pycnical constitutional types could perform the greatest joint range of motions in the large joints of the upper limb [46]. It was found that the prevailing number of women with 
autoimmune toxic thyroiditis (33.4\%) has an athletic type of constitution in the study of the constitutional predisposition to endocrine diseases [47].

The study of the relationship between the constitutional type of woman and the frequency of complications of pregnancy and childbirth showed that gestosis and threatening miscarriage are most often observed in women with picnic type of constitution (63.6\% and $40.5 \%$ of cases respectively) and significantly less (in $17.4 \%$ and $21.7 \%$ of cases) in women with asthenic but colpitis, bacterial vaginosis, intrauterine infection of the fetus are more often noted in women with asthenic type of constitution [48].

Grebennikova showed that the majority of patients with hyperplastic diseases of the uterus were women with the megalosomal type of constitution - 84.8\%. $32.4 \%$ women had athletic somatotype, $8.6 \%$ women had subtleties and $59.0 \%$ women had euryplastic somatotypes. Mesosomal type of constitution had $11.0 \%$ of women (mesoplastic somatotype) and 4.3\% women had leptosomal constitution. Women with asthenic and stenoplastic somatotypes were observed in $57.2 \%$ and $42.9 \%$ cases respectively [49].

Prokopiev showed that dimensions of the inner arch are less than the usual values only in stand-up men with asthenic somatotype after fractures of the shin bones, that's why these men are recommended to use insoles for the support of the longitudinal arch of the foot [50].

Russkich has shown that stress urinary incontinence is more rarely seen in women with mesomorphic (normosthenic) type of physique studying the constitutional features of the structure of the urethra and the neck of the bladder in women [51]. The clinical features of chronic prostatitis are more expressed in patients with chest somatotype in combination with early onset of the disease (27.1 \pm 0.5 years). Men with abdominal type of constitution have not so expressed symptomatology and the onset of manifestations, in this case, is at the age of $28.8 \pm 0.6$ years, and the minimal clinical manifestations are combined with the intermediate age between the first and second age group of the disease in persons with the muscular type of constitution [52].

Modern studies have shown that there is a high prevalence of non-alcoholic liver disease (the most severe form of which is nonalcoholic steatohepatitis) among people with type 2 diabetes mellitus and obesity particularly [53]. In the study of constitutional markers of predisposition to obesity, it was found that picnic type of the constitution is more often noted among women with obesity of the $1^{\text {st }}$ degree, euryplastic type is noted in women with obesity of the $2^{\text {nd }}$ and $3^{\text {rd }}$ degrees; abdominal type is noted among men. Abdominal-muscular type of constitution is observed among men at the age of $22-25$ years, obesity of the $3^{\text {rd }}$ degree is observed mainly in $94.5 \pm 0.4 \%$. Low probability of obesity development (in the presence of cardiovascular pathology) is combined with asthenic, stenoplastic, picnic and subtleties somatotypes in women and it is also combined with the muscular type of constitution in men $[35,54]$.

Body weight deficiency is noted in persons with stenoplastic type of constitution among women of the second period of mature and at elderly age [25].

It is noted that the sexual activity under the age of 40 is maximal in men with the muscular type of the constitution and minimal in men with thoracic type; men with this somatotype are at risk of developing erectile dysfunction (74\% of cases) [55]. However some authors assessing the reproductive function found that young men with a thoracic type of constitution had the highest testosterone level in the blood serum (an average of 8.6 $\mathrm{ng} / \mathrm{ml}$ ), the highest concentration of spermatozoa (an average of $93.5 \mathrm{million} / \mathrm{ml}$ ) and their mobility (62\%); the lowest values were noted for an indefinite constitutional type [56].

\section{Conclusion}

These literature data indicate the availability of correlations between the type of the human constitution, the probability of development, severity, and prognosis of diseases. Thus, the search of phenotypic predictors of various functional and pathological conditions is a complex problem of modern personified medicine worldwide. Competent and timely use of somatotyping will allow selecting the methods of treatment and prevention of diseases more objectively.

\section{Conflict of interest: none declared.}

\section{References}

1. Tutelian VA, Razumov AN, Klochkova SV, Alexeeva NT, Rozhkova EA Kvaratskhelia AG, Nikitiuk DB. Features of macro-anthropometric parameters in women of different somatotypes. Morphological Newsletter 2017; (1): 20-22. Russian. https://elibrary.ru/item.asp?id=29064033.

2. Acharya J, Shetty BSK, Shrestha R, Kanchan T. Approximation of height of an individual using somatometry of human male skull. JNMA J Nepal Med Assoc 2017; 238-242. https://www.ncbi.nlm.nih.gov/pubmed/28746322.

3. Aune D, Norat T, Vatten LJ. Body mass index, abdominal fatness and the risk of gallbladder disease. Eur J Epidemiol 2015; 30(9): 1009-1019. https://doi.org/10.1007/s10654-015-0081-y.

4. Barrios C, Cortés S, Pérez-Encinas C, Escrivá MD, Benet I, Burgos J, et al. Anthropometry and body composition profile of girls with nonsurgically treated adolescent idiopathic scoliosis. Spine 2011; 36(18): 1470-1477. https://doi.org/10.1097/BRS.0b013e3181f55083.

5. Fursov $A B$, Fursov RA. Correlation of anthropometric parameters in patients with metabolic syndrome before endoscopic gastro-bypass surgery. European Journal of Natural History 2016; (1): 5-6. https://elibrary.ru/item.asp?id=26017658.

6. Pinelli C, Garcia PN, Soares DD, Quirino LC, Campos JA. Reproducibility of static antropometric measurments of undergraduate dental students in dental schools. Pesquisa Brasilleria em Odontopediatria e Clinica Intergrada 2011; 11(1): 21-27. Portugues. http://dx.doi.org/10.4034/pboci.v11i1.1250.

7. Nikolenko VN, Nikitiuk DB, Chava SV. Domestic constitutional anatomy in the aspect of personalized medicine. Sechenovsky Vestnik 2013; (4) 9-17. Russian. https://elibrary.ru/item.asp?id=21984756.

8. Rumyantsev NA, Sychev DA, Kukes VG, Kazakov RE, Rumyantsev AA, Taratuta TV. Experience of individualization of oral anticoagulants use and dosage in personalized medicine centre conditions. Kazan Medical Journal 2015; 96(6): 1065-1068. Russian. https://elibrary.ru/item.asp?id=24859668.

9. Da Silva GV, Halpern M, Gordon CC. Anthropometry of Brazilian Air Force pilots. Ergonomics 2017; 60(10): 1445-1457. https://doi.org/10.1080/00140139.2017.1301575.

10. Rotar OP, Trifonova EA, Korostovtseva LS. Health behaviors and attitudes in young and middle-aged Saint-Peterburgs citizens (Russia): a pilot student. J Addict Res Ther 2012; S8: 003. https://doi.org/10.4172/2155-6105.S8-003.

11. Kukes VG, Olefir UV, Prokofiev AB, Shih EV, Marinin VF, Ramenskaya $\mathrm{GV}$, et al. Implementation of personalized medicine in Russia:clinical pharmacologist's view. Clinical Pharmacology and Therapy 2016; 25(5): 14-17. Russian. https://elibrary.ru/item.asp?id=29246886. 
12. Yu W, Ma M, Chen X, Min J, Zheng Y, Li Y, et al. Traditional Chinese medicine and constitutional medicine in China, Japan and Korea: a comparative study. Am J Chin Med 2017; 45(1): 1-12. https://doi.org/10.1142/S0192415X1750001X.

13. Nikitiuk DB, Nikolenko VN, Klochkova, SV, Minnibaev TSh. Body mass index and other anthropometric parameters of the physical state in relation with age and individual-typological specific of women constitution. Voprosy Pitaniya 2015; 84(4): 47-54. Russian. https://elibrary.ru/item.asp?id=24100342.

14. Razumov AN, Election KV, Pogonicheva IV, Rozhkova EA, Akaeva NT, Klochkova SV, et al. Main indicators of physical development and somatotypological features of men in older age groups. Voprosy $\begin{array}{llll}\text { Pitaniya 2017; 86(2): } & \text { 32-39. }\end{array}$ https://elibrary.ru/item.asp?id=28990187.

15. Tutelian VA, Razumov AN, Nikitiuk D B, Rozhkova EA, Klochkova SV, Alexeeva NT, et al. Features of physical development of senile age and long-liver women. Journal of Anatomy and Histopathology 2016; 5(1): 9-14. Russian. https://elibrary.ru/item.asp?id=25672466.

16. Vasil'eva TE, Marinova LG, Tikhonov AS, Savina NV. Bioimpedance analysis of body composition in school-age children are overweight Medical rehabilitation in Pediatrics. In: Practice, achievements, problems and prospects: collection of scientific works. Yakutsk, Russia, 2013: 56-63. Russian.

17. Gur'eva AB, Alekseeva VA, Degtyareva TG, Petrova PG, Nikolaev VG. The individual typological features of physical status of women of the Sakha Republic (Yakutia) in the age aspect. In: Ecology and health in the North: collection of scientific works. Yakutsk, Russia, 2013: 171176. Russian.

18. Kuznetsov VV, Novikov AA. Technical implementation of polyfrequency bioimpedance spectrometry in diagnosis studies. Omsk Scientific Bulletin 2013; (2): 272-277. Russian. https://elibrary.ru/item.asp?id=20800019.

19. Rakhmatullina LN, Gurevich KYa. Application bioimpedance body composition monitor $(\mathrm{BCm})$ in clinical practice in dialysis patients (literature review). Nephrologia 2013; 17(4): 49-57. Russian. https://elibrary.ru/item.asp?id=20297501.

20. Yampolskaya YA. Gracielization and types of Constitution: populational and intra-group variability (the second half of the twentieth century, Moscow, Russia). Anthropology Bulletin 2016; (2): 117-126. Russian. https://elibrary.ru/item.asp?id=29101531.

21. Akulov SA, Doroshenko YZ. Cell suspensions status monitoring by bioimpedance method. VESTNIK of Samara University. Aerospace and Mechanical Engineering 2012; (7): 97-102. Russian. https://elibrary.ru/item.asp?id=20419632.

22. Nikitiuk DB, Nikolenko VN, Khairullin RM, Minnibaev ST, Chava SV, Alexeeva NT. The anthropometric method and clinical medicine. Journal of Anatomy and Histopathology 2013; 2(2): 10-14. Russian. https://elibrary.ru/item.asp?id=21028051.

23. Petukhov AB, Maev IV, Deryabin VE. Anthropometry: the modern statistical analysis and significance for internal medicine and nutrition. Voprosy Pitaniya 2012; 81(3): 82-91. Russian. https://elibrary.ru/item.asp?id=17909155.

24. McElroy A, Townsend PK. Medical antropology in ecological perspective. 4th ed. Boulder: Westview Press, 2004; 466 p.

25. Bukavneva NS, Pozdnyakov AL, Nikityuk DB. Methodical approaches to usage of complex anthropometric study in clinical practice. Voprosy $\begin{array}{llll}\text { Pitaniya 2007; 76(6): 13-16. Russian. } & \end{array}$ https://elibrary.ru/item.asp?id=15259330.

26. Markova EV, Zakharova LB, Nikolaev VG, Susilo EV. Morphofunctional peculiarities of blood lymphocytes and body type. Morphology 1996; 109(2): 70. Russian.

27. Bunak VV. Anthropometry. Moscow, Russia, 1941; 368 p. Russian.

28. Martirosov EG, Nikolaev DV, Rudnev SG. Technologies and methods of determining the composition of the human body. Moscow: Nauka, 2006; 247 p. Russian.
29. Galant IV. New scheme of constitutional types of women. Kazan Medical Journal 1927; (7): 23-34. Russian.

30. Nikityuk BA, Chtetsov VP. Morphology of the person. Moscow: Moscow University, 1983; 320 p. Russian.

31. Kliorin Al, Chtetsov VP. Biological problems of the doctrine of the human Constitution. Moscow: Nauka, 1979: 349 p. Russian.

32. Nikolaev VG, Efremov VP, Oleinikov BV, Saraikin EN, Ignatieva ES. Topical issues of physical health situation of the population in the collection. In: Current issues in biomedical and clinical anthropology. Krasnoyarsk, 1997: 67-71. Russian.

33. Kapustina EV, Bol'shakova TYu, Nikulina SYu, Sharaikina EP, Chupakhina VA. Constitutional portraits of women with osteoarthritis in the age aspect. Health \& Education in the XXI Century 2016; 18(6): 31-34. Russian. https://elibrary.ru/item.asp?id=26584617.

34. Rudenko PG, Nikolaev VG, Dralyuk MG. Severity of radicular fallout for herniated discs L4-L5 in women with different types of constitution. Siberian Medical Review 2002; (3): 37-39. Russian. https://elibrary.ru/item.asp?id=12567705.

35. Bukavneva NS, Nikityuk DB. Constitutional peculiarities of patients with alimentary dependent pathology. Morfologicheskie Vedomosti 2008; (1-2): 145-146. Russian. https://elibrary.ru/item.asp?id=14750256.

36. Nikolenko VN, Golovacheva TV, Petrova VD, Yakimova NS. Constitutional features of patients with myocardial infarction of men in Saratov region depending on body type. In: Aktualnye problemi sovremennoj morfologii. SPb, Russia, 2008: 214-218. Russian.

37. Yakimova NS. Clinical course and risk factors for myocardial infarction of men and women of different somatotype. PhD dissertation abstract. Saratov, Russia, 2008; 21 p. Russian.

38. Nikulina SYu, Shulman VA, Puzyrev VP, Salyukov VB, Vorotnikova YuV. Constitutional characteristics of patients with impaired cardiac conduction. In: Aktualnye voprosy biomedicinskoj i klinicheskoj antropologii. Krasnoyarsk, 1997: 147-148. Russian.

39. Petrova MM, Romanova IV, Shtarnak SYu, Belova EO. The relationship between acute myocardial infarction and the constitution of human. In: Aktualnye voprosy biomedicinskoj i klinicheskoj antropologii. Krasnoyarsk, 1997: 151-154. Russian.

40. Vladimirova YB. Constitutional peculiarities of men of the heart in normal conditions and in hypertrophy of the left ventricle. PhD dissertation abstract. Krasnoyarsk, Russia, 2001; 18 p. Russian.

41. Cherkashina II, Nikulina SYu, Liberdovskaya ED, Chupakhina VA, Sharaikina EP, Shestovitskii VA, Komarova MA. Genealogical and anatomical analysis of families of patients with bronchial asthma Siberian Medical Review 2012; (6): 28-33. Russian. https://elibrary.ru/item.asp?id=18757775.

42. Bankova OA, Nikolaeva NN. Clinical and functional symptoms of biliary dyskinesia in women megalomania of the constitution. In: Current issues in biomedical anthropology. Krasnoyarsk, Russia, 1997: 117-118. Russian.

43. Nikolaeva NN, Baykov OA, Nikolaeva LV. Peculiarities of motility of gallbladder in women of different somatotypes and drug correction of its hypokinesias. Siberian Medical Review 2009; (2): 38-42. Russian. https://elibrary.ru/item.asp?id=12533687.

44. Shaposhnikov AV, Nefedov VI, Shaposhnikov SA. Anthropometric indices in patients with liver cirrhosis and chronic hepatitis. In: Constitution and health of man. Leningrad, Russia, 1999: 70. Russian.

45. Polismak OV. Characterization of the anatomical components of the somatotype of person's youthful and first period of mature age in norm and in some diseases of the digestive system. PhD dissertation abstract. Volgograd, Russia, 2005; 20 p. Russian.

46. Derevtsova SN, Nikolaev VG, Prokopenko SV, Zaytseva OI. Neurorehabilitation syndrome of the central hemiparesis in men and women with different type of constitution in the late residual period Modern Problems of Science and Education 2014; (5): 478. Russian. https://elibrary.ru/item.asp?id=22566880. 
47. Vartanova ОT. Characterization of the anatomical components of the somatotype of healthy people, residents of southern Russia youthful and first period of mature age, and dysfunction of certain endocrine glands. PhD dissertation abstract. Volgograd, Russia, 2003; 22 p. Russian.

48. Shatrova OV. Features of fetal development and functional status of the fetus in women of different somatotype. PhD dissertation abstract. Krasnoyarsk, Russia, 2004. 22 p. Russian.

49. Grebennikova EK, Tskhai VB, Medvedeva NN. Constitutional features of women with hyperplastic diseases of the uterus. Siberian Medical Review 2012; (4): 37-40. Russian. https://elibrary.ru/item.asp?id=17909469.

50. Prokop'ev AN, Sergeev KS, Mazur VA. The anatomist-functional particularity ankle joint and foots beside mans of the first mature age with consequence diaphysial fracture shank. Medical Science and Education of the Urals 2009; 10(1): 105-106. Russian. https://elibrary.ru/item.asp?id=22797853.

51. Russkikh AN. Constitutional features of the structure of the urethra and bladder neck in women. PhD dissertation abstract. Krasnoyarsk, Russia, 2009; 25 p. Russian.

52. Vinnik YY. Constitutional characteristics of clinical manifestations, functional and microcirculatory disturbances in chronic prostatitis urethrogram. PhD dissertation abstract. Krasnoyarsk, Russia, 2000; 23 p. Russian.

53. Pavlov ChS, Kuznetsova EA, Arslanian MG, Semenistaya MC, Glushenkov DV, Nikolenko VN. Non-alcoholic fatty liver disease: modern concepts of etiology, pathogenesis, diagnostics and treatment. Medical Bulletin of the North Caucasus 2017; 12(2): 230234. Russian. https://elibrary.ru/item.asp?id=29805837.

54. Tutelyan VA, Gapparov MG, Baturin AK. The usage of complex method anthropometry in clinical practice for the evaluation of physical development and nutritional status of healthy and diseased human. Moscow, Rusia: Ares, 2008; 48 p. Russian.

55. Pomilujkova EO. Constitutional features of erectile dysfunction and penile structure. PhD dissertation abstract. Krasnoyarsk, Russia, 2003; 25 p. Russian.

56. Burgart VYu. Morphological and functional features of the genitals of boys depending on the somatotype. PhD dissertation abstract. Krasnoyarsk, Russia, 2006; 22 p. Russian.

\section{Authors:}

Vladimir G. Kukes - Academician of the Russian Academy of Sciences, MD, DSc, Professor, Department of Clinical Pharmacology and Propaedeutics of Internal Medicine, I.M. Sechenov First Moscow State Medical University, Moscow, Russia.

Vladimir N. Nikolenko - MD, DSc, Professor, Head of Human Anatomy Department, I.M. Sechenov First Moscow State Medical University, Moscow, Russia; Head of Department of Normal and Topographic Anatomy, Lomonosov Moscow State University, Moscow, Russia. https://orcid.org/0000-0001-9532-9957.

Chavdar S. Pavlov - MD, DSc, Professor; Professor of Department of Propaedeutics of Internal Medicine, Faculty of Physiology, I.M. Sechenov First Moscow State Medical University, Moscow, Russia; Head of Research Department of Innovative Therapy, I.M. Sechenov First Moscow State Medical University, Moscow, Russia. https://orcid.org/0000-0001-5031$\underline{9798}$

Tatiana S. Zharikova - MD, PhD, Senior Lecturer, Human Anatomy Department, Faculty of Physiology, I.M. Sechenov First Moscow State Medical University, Moscow, Russia. https://orcid.org/0000-0001-6842$\underline{1520}$

Valeriy F. Marinin - MD, DSc, Professor, Department of Clinical Pharmacology and Propaedeutic of Internal Diseases, I.M. Sechenov First Moscow State Medical University, Moscow, Russia.

Leonid A. Gridin - MD, DSc, Professor, Department of Integrative Medicine, Institute of Professional Education, I.M. Sechenov First Moscow State, Moscow, Russia. 